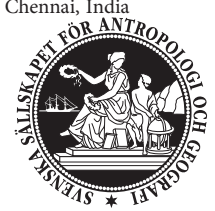

\title{
Rock glaciers in central Patagonia
}

\author{
Heather Selley ${ }^{\mathrm{a}}$, Stephan Harrison ${ }^{\mathrm{b}}$, Neil Glasser ${ }^{\mathrm{c}}$, Olaf Wündrich ${ }^{\mathrm{d}}$, Daniel Colson ${ }^{\mathrm{e}}$ and \\ Alun Hubbard ${ }^{\mathrm{f} g}$
}

${ }^{a}$ Centre for Polar Observation \& Modelling, University of Leeds, Leeds, UK; ${ }^{b}$ College of Life and Environmental Sciences, Exeter University, Penryn, UK; 'Department of Geography and Earth Sciences, Aberystwyth University,

AQ1 Wales, UK; ${ }^{\mathrm{d}}$ Predio Ana-Rosi, Comuna y Provincia de Coyhaique, Chile; ${ }^{\mathrm{e}}$ Joint Nature Conservation Committee (JNCC),

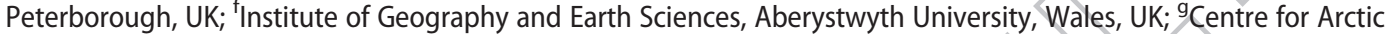
Gas Hydrate, Environment and Climate, UiT - The Arctic University of Norway, Tromsø, Norway

\section{ABSTRACT}

Active rock glaciers are ice and debris-cored landforms common in cold arid mountains. They have not been widely described in the Patagonian Andes of southern South America and here we provide the first rock glacier inventory for the Jeinimeni region to the east of the contemporary North Patagonian Icefield. Detailed analysis of available satellite imagery and fieldwork demonstrates the presence of 89 rock glaciers across the study region, covering a total of $14.18 \mathrm{~km}^{2}$. Elevation is the primary control on rock glacier distribution with $89 \%$ existing between 1600 and 1900 m.a.s.l. Aspect also plays a significant role on rock glacier formation with $80 \%$ preferentially developed on southerly slopes receiving lower solar insolation.

\section{Introduction}

Rock glaciers are cryospheric landforms formed by the accumulation of ice and debris (Brenning AQ2 et al. 2012; Lui et al. 2013) that creep downslope by the deformation of internal ice (Barsch 1996; Haeberli et al. 2006; Berthling 2011; French and Williams 2013, Benn and Evans 2014). Commonly, rock glaciers have extremely slow flow rates, typically only a few centimetres a year (Stenni et al. 2007) and the viscous flow of the debris and ice matrix produces a distinctive surface of ridges, furrows and a steep frontal slope ('toe' or 'snout') (Barsch 1996; Degenhardt and Giardino 2003; Paul et al. 2003; Haeberli et al. 2006; Jansen and Hergarten 2006; Berthling 2011). They play a significant role controlling sediment supply in mountainous regions, accounting for up to $\sim 60 \%$ of all mass transport in some mountainous areas (Degenhardt 2009). The high insulation capacity of the surface rock cover has been demonstrated to slow the melt of ice within rock glaciers compared to glaciers

AQ3 (Stenni et al. 2007; Gruber et al. 2017); they therefore potentially represent important sources of freshwater runoff in semi- and arid-mountains (e.g. Brenning 2005; Rangecroft et al. 2014).

There has been considerable debate over the origin of rock glaciers based on assessment of their internal structure (Potter 1972; Barsch 1978; Whalley and Martin 1992; Humlum 1996; Haeberli et al. 2006; Krainer and Ribis 2012). Two main schools of thought have emerged: the 'permafrost school' versus the 'continuum school' (Berthling 2011). Additionally, a landslide model of development has been proposed (Johnson 1974; Whalley and Martin 1992). Despite the considerable amount of research undertaken to understand the origin of rock glaciers, little consensus has been achieved. However, most workers accept that they reflect persistent permafrost conditions

CONTACT Stephan Harrison stephan.harrison@exeter.ac.uk College of Life and Environmental Sciences, Exeter University, Cornwall Campus, Penryn, TR10 9EZ, UK

(c) 2018 Swedish Society for Anthropology and Geography 
(e.g. Berthling 2011). In many regions rock glaciers are currently developing from glaciers and debris-covered glaciers (Shroder et al. 2000; Monnier and Kinnard 2015) and this evolution is likely to continue given future climate warming (Jones et al. 2018).

The large-scale distribution of active rock glaciers is predominantly controlled by climate. They are concentrated in periglacial areas characterized by low temperatures and low insolation on shaded slopes with plentiful debris supply from talus slopes and rock headwalls (e.g. White 1979; Parson 1987; Brenning 2005; Berthling and Etzelmüller 2007; Summerfield 2014). Topographic factors, such as cirque width, the degree of rock wall fracture and, the height of bounding rock headwalls contribute to varying levels of debris supply (Chueca 1992) and it has been hypothesized that rock headwalls play a crucial role in determining the environmental niches within which rock glaciers may develop (Olyphant 1983; Burger et al. 1999; Haeberli et al. 1999, 2006; Humlum 2000). A consensus has emerged which argues that rock glaciers require suitable niches in which to develop, determined by a combination of three dominant characteristics: low solar insolation, sufficient talus supply to maintain them and climatic conditions conducive to the development of perennial ice. The degree of influence of these environmental and geological conditions varies regionally, suggesting a complex interplay of topoclimatic factors in driving rock glacier development (Kinworthy 2016).

Rock glaciers can be classified according to their activity status (Wahrhaftig and Cox 1959) as active, inactive and fossil (relict). Active rock glaciers move downslope through gravity-driven creep as a consequence of the deformation of ice they contain (Barsch, 1992,1996). Commonly, active landforms are characterized by flow-like features (i.e. spatially organized morphometric features, e.g. distinctive surface micro-relief of furrow-and-ridge topography), steep $\left(\sim 30-35^{\circ}\right)$ and sharp-crested front- and lateral-slopes, a 'swollen' appearance of the rock glaciers body, individual lobes, and an absence of vegetative cover (Martin and Whalley 1987; Haeberli et al. 2006; Harrison et al. 2008). These distinctive morphometric features reflect the viscoplastic properties of the rock glacier. Inactive rock glaciers also contain ice, but are immobile (e.g. Seligman 2009).

The presence of rock glaciers in either their active or relict forms has been widely used as permafrost and climatic indicators. For instance, the altitude of rock glacier termini or fronts (minimum altitudinal fronts or MAF) are assumed to mark the lower limit of discontinuous permafrost (Giardino and Vitek 1988; Barsch 1996). Moreover, the active layer with insulating debris surface covers the ice acting as buffer against high frequency (i.e. seasonal to diurnal) temperature fluctuations (Angillieri 2009). The degradation of permafrost and therefore rock glaciers, associated with projected atmospheric warming, can therefore impact water supplies in the dry Andes and other arid mountain regions (e.g. Trombotto et al. 1999; Brenning 2005; Rangecroft et al. 2015).

Many rock glacier inventories have been created to establish their regional significance and distribution to better understand the environmental variables controlling development and, recently, their potential role as buffered hydrological stores (Schrott 1996; Brenning 2005; Rangecroft et al. 2013, 2014). Rock glacier inventories have been created from many of the world's mountain regions including the European Alps (e.g. Dramis et al. 2003; Kellerer-Pirklbauer et al. 2012; Marcer et al., 2017), Newland Alps (Sattler et al., 2016), the Pyrenees (e.g. Chueca 1992), North American Sierra Nevada (e.g. Millar and Westfall 2008) and the central parts of the South American Andes (e.g. Trombotto et al. 1999; Brenning 2005; Rangecroft et al. 2014). However, relatively little attention has been paid to the southern Andes until recently (e.g. Falaschi et al. 2015). Here we develop a first rock glacier inventory for the mountains to the south of Lago General Carrera/Buenos Aires between the borders of Chile and Argentina and investigate primary controls on their distribution.

\section{Study region}

Our study region lies in the Jeinimeni National Reserve in Chilean territory in the Central Patagonian Andes on the Chilean and Argentinean border at $46^{\circ} 52^{\prime} 0^{\prime \prime} \mathrm{S}, 72^{\circ} 4^{\prime} 0^{\prime \prime} \mathrm{W}$ (Figure 1). It is situated directly east of the North Patagonian Icefield (NPI), one of three major ice masses which currently exist in southern South America (Harrison and Glasser 2011). Previous fieldwork in the 


\section{$72^{\circ} 00^{\prime} 00.00^{\prime \prime} \mathrm{W}$}
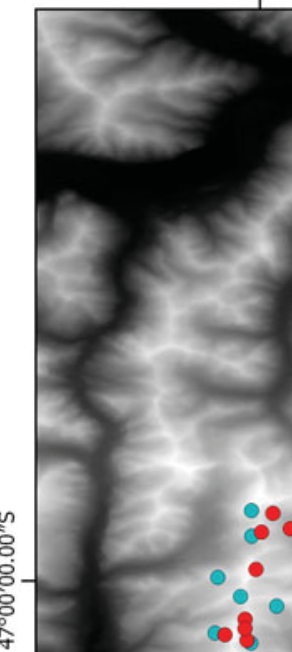

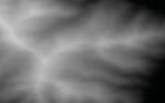
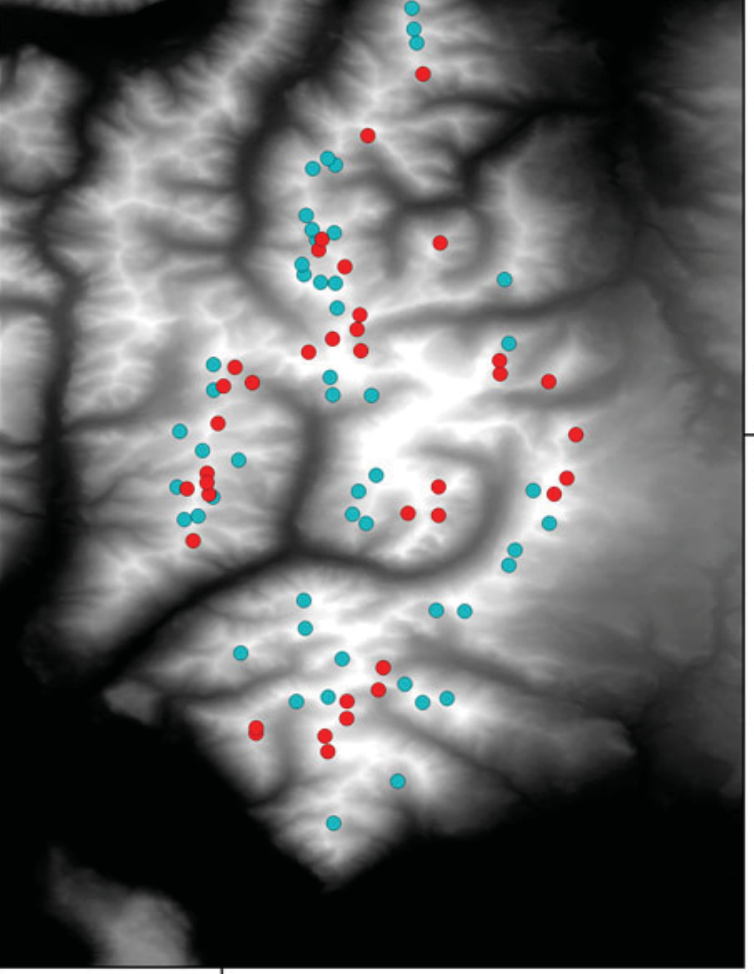

$72^{\circ} 00^{\prime} 00.00^{\prime \prime} \mathrm{W}$

\begin{abstract}
0
\end{abstract}
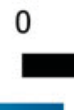

Precipitation (mm/year)

$$
0
$$

2544

DEM (m.a.s.l.)
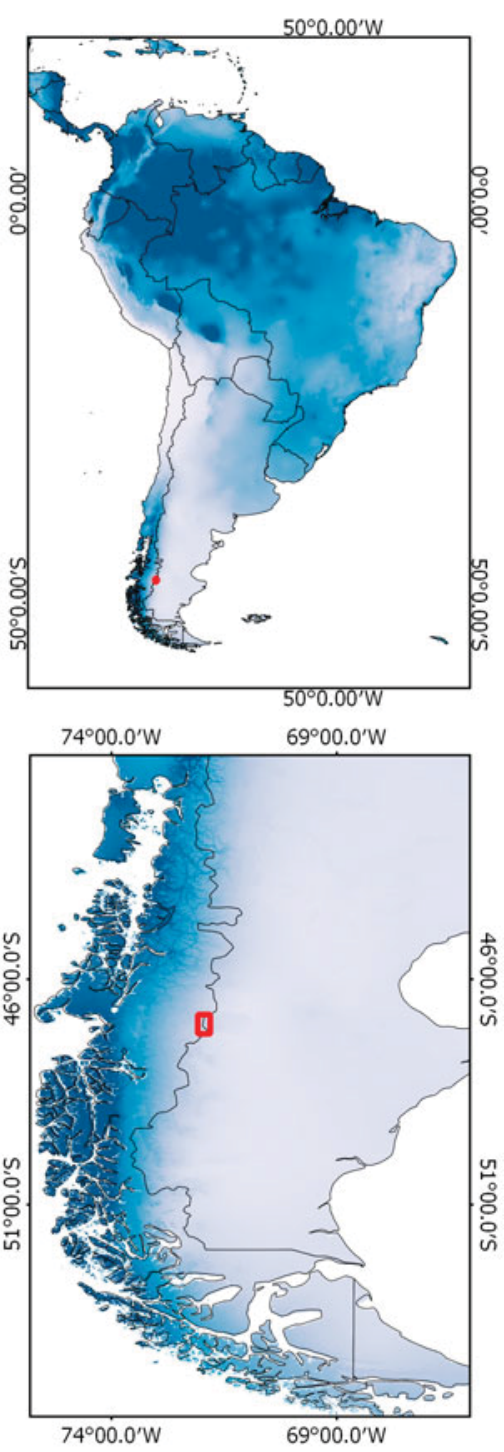

Figure 1. Location map illustrating the steep precipitation gradient west to east across Patagonia. Top left: location of rock glaciers. AQ4 Image data: Aster GDEM product of NASA and METI (2009). Top right and bottom right: mean annual precipitation rates using WorldClim (http://worldclim.org) $0.5^{\circ}$ resolution data for 1970-2000. The Jeinimeni Region study area is identified located east of the North Patagonian Icefield.

southern side of the area making up the National Reserve identified rock glaciers in the mountains between Cerro Tamango $(1712 \mathrm{~m})$ at the western end of the Chacabuco Valley and Cerro Opportus (2021 m) 34km to the east. The regional climate is dominated by the Southern Hemisphere westerlies and proximity to the Pacific Ocean (Villarroel et al. 2013). The presence of the NPI to the west produces an extremely steep west-east precipitation gradient (Figure 1) and the Jeinimeni region lies in the rainshadow of the NPI with low annual precipitation (Figure 1). Glacier development here is hence severely limited by regional precipitation availability. During the late Pleistocene, fast flowing outlet lobes of an expanded Patagonian Ice Sheet (PIS) extended eastwards along the Chacabuco 
Valley to the south of Jeinimeni and to the north to the east of Lago Buenos Aires. Only the highest mountains in the region remained uncovered by ice during the Last Glacial Maximum (LGM) at around 24-22.5 ka BP (Hubbard et al. 2005; Boex et al. 2013).

\section{Methods}

We developed the rock glacier inventory using photomorphic mapping from Google Earth Imagery (5-30 m resolution) (version 7.1.7.2606, Google Inc., California, USA) (e.g. Rangecroft et al. 2014; Schmid et al. 2015). The multi-temporal data available through Google Earth reduces uncertainty in landform identification due to clouds, shadows and snow cover by enabling a full inventory of the area by mosaicking imagery with varying dates between 2007 and 2015. Google Earth Pro data are exportable as KML file for further spatial analysis within GIS software (e.g. ArcMap) (e.g. Schmid et al. 2015). Manual feature identification using geomorphic indicators and subsequent AQ5 digitization was carried out (Baroni et al. 2004; Falaschi et al. 2014; Rangecroft et al. 2014; Jones et al. 2018). To ensure comparability and accuracy polygons were reprojected to the WGS84 coordinate system. Topographic data were extracted for the polygons and central flow lines from a $\sim 30 \mathrm{~m}$ resolution digital elevation model (DEM), NASA version 3.0 Shuttle Radar Topography Mission (SRTM) Global 1 arc-second dataset (USGS 2015) within ArcMap (Schmid et al. 2015; Jones et al. 2018).

Rock glaciers were identified using two principal characteristics: 1) distinctive surface morphology of ridges and furrows, formed as a result of compression and extension and produced by differential ice and debris distribution and flow, and; 2) steep frontal slope indicative of the limit of viscous flow of internal ice (e.g. Barsch 1996; Haeberli et al. 2006; Berthling 2011). Several rock glaciers along the southern margin of the study area (to the east of Cerro Tamango) were verified by field observation.

Rock glacier boundary digitization follows Scotti et al. (2013) and Jones et al. (2018) methodology. Polygons were digitized for each rock glacier identified, landforms were defined and classified according to a well-established criteria (see Table 1). For each rock glacier, key characteristics were identified and measured using the ruler tool and geometry calculations in Google Earth Pro (Figure 2). Delineation of rock glaciers is challenging, digitizing the upper boundary can be arbitrary without data movement and evident furrow-and-ridge formations in the rooting zone (Roer and Nyenhuis 2007; Krainer and Ribis 2012; Jones et al. 2018). Rock glaciers were distinguished from other periglacial landforms, such as protalus ramparts or lobes, by an application of a length: width ratio of less than 1 (unity) (Harrison et al. 2008: Jones et al. 2018). Coalesced rock glaciers were differentiated from their source headwalls or talus slopes (Jones et al. 2018).

The activity status of the rock glaciers was established based on assumed ice content using the morphological classification system by Barsch (1996) (Table 1 and Figure 3). This uses geomorphological and morphological criteria, including steepness of frontal slope, and development of thermokarst pits indicating ice content. Rock glaciers were classified as "Relict" and "Active" which includes both active and intact landforms (Jones et al. 2018).

Slope aspect is a key factor in the development of rock glaciers and this was determined using the ArcMAP aspect spatial analyst tool, which divides aspect into 8 groups by proportioning-out bearings of $0^{\circ}$ to $360^{\circ}$ (Burrough et al. 2015). Aspect density analysis was also undertaken according to

Table 1. Characteristics of rock glaciers in the Jeimimeni region.

\begin{tabular}{lccccccc}
\hline & $\begin{array}{c}\text { Number } \\
(\%)\end{array}$ & $\begin{array}{c}\text { Maximum Elevation } \\
(\mathrm{m})\end{array}$ & $\begin{array}{c}\text { Elevation Range } \\
(\mathrm{m})\end{array}$ & $\begin{array}{c}\text { MAF } \\
(\mathrm{m})\end{array}$ & $\begin{array}{c}\text { Ground Length } \\
(\mathrm{m})\end{array}$ & $\begin{array}{c}\text { Ground Width } \\
(\mathrm{m})\end{array}$ & $\begin{array}{c}\text { Area } \\
\left(\mathrm{m}^{2}\right)\end{array}$ \\
\hline Intact & $51(57 \%)$ & 1941 & 179 & 1766 & 583 & 270 & 156000 \\
Relict & $38(43 \%)$ & 1919 & 162 & 1758 & 595 & 332 & 164000 \\
\hline
\end{tabular}




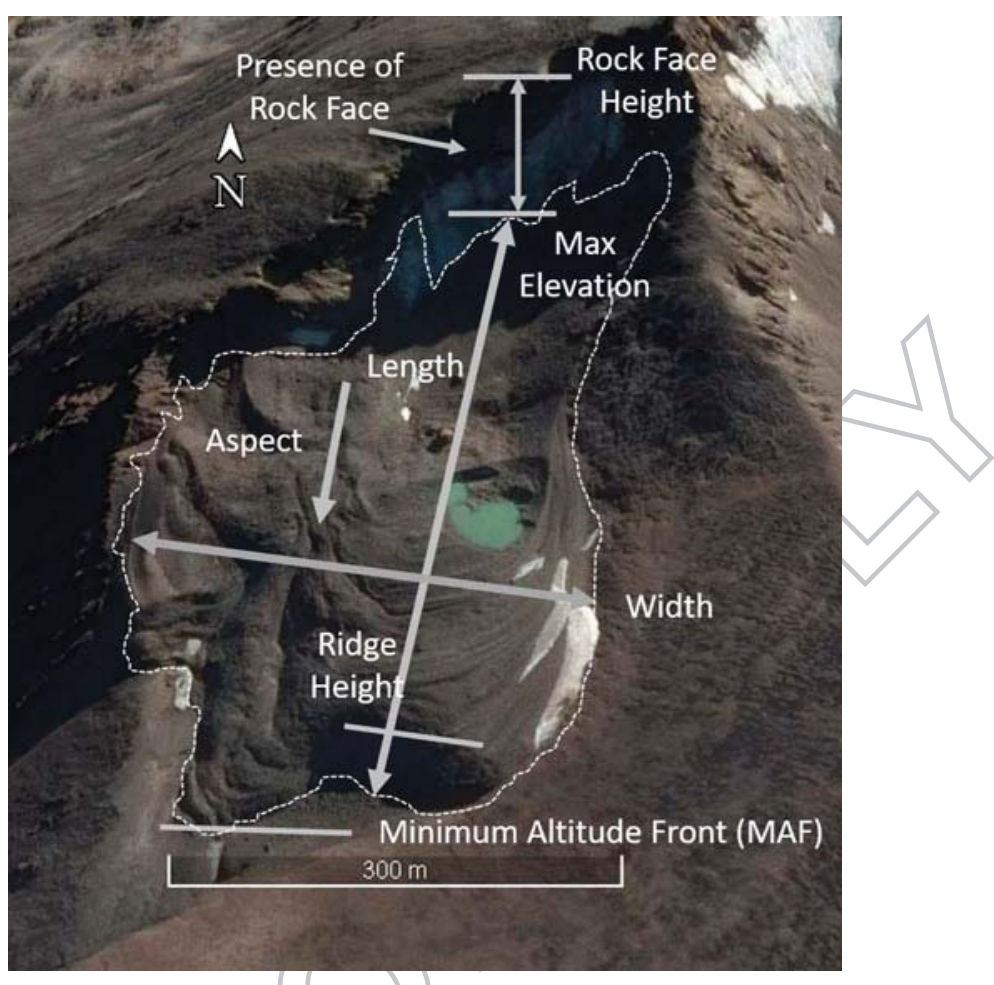

Figure 2. Annotated example of characteristics extracted for each of the rock glacier measured. Other characteristics recorded were: surface area, average elevation as well as the maximum, minimum and average slope angle along the central flow line $\left(46^{\circ} 58^{\prime} 30.86^{\prime \prime} \mathrm{S} 72^{\circ} 00^{\prime} 13.94^{\prime \prime} \mathrm{W}\right)$. Image data: Google Earth Imagery (version 7.1.7.2606, Google Inc., California, USA), CNES/Airbus 2018; imagery date: 16 March 2016.

the analysis of Falaschi et al. (2015). The areas of each aspect for the study area were calculated, and a density analysis carried out to establish the percentage of the study area facing each direction. The proportion of rock glaciers located on each aspect was then plotted against the aspect density of the study region.

To further assess the influence of solar radiation on rock glacier development in the region the Potential Incoming Solar Radiation (PISR) was calculated for the study using the 'Area Solar Radiation' toolbox in ArcMap. A mean figure was calculated for each of the years of imagery available from 2007 to 2015, a mean raster layer was produced and zonal statistics extracted to create the mean PISR value for each rock glacier polygon. The Non-parametric data set was tested for significance using Mann-Whitney $\mathrm{U}$ tests.

\section{Results}

In total, 89 rock glaciers were identified and mapped and these cover $14.18 \mathrm{~km}^{2}$ of the study area $\left(1381.84 \mathrm{~km}^{2}\right)$. The inventory comprises 51 active rock glaciers (covering $7.94 \mathrm{Km}^{2}$ ) and 38 relict rock glaciers (covering $6.24 \mathrm{Km}^{2}$ ). A summary of rock glacier characteristics based on the classification of active and relict features is shown in Table 2. Rock glaciers occurred between 1412 and 2049 m.a.s.l and $89 \%$ of total rock glaciers between 1600 and 2000 m.a.s.l. (Figure 4). 92\% of the rock glaciers identified can be classified as tongue shaped. The MAF for active (1766 \pm 128 m.a.s.l.) and relict rock (1758 \pm 133 m.a.s.l.) glaciers shows a similar distribution (see Figure 6) and Chi Squared tests found there was no significant difference between the MAF of active and relict rock glacier populations: $\left(\mathrm{X}^{2}(1, \mathrm{~N}=89)=0.151, \mathrm{p}=0.697\right)$. 


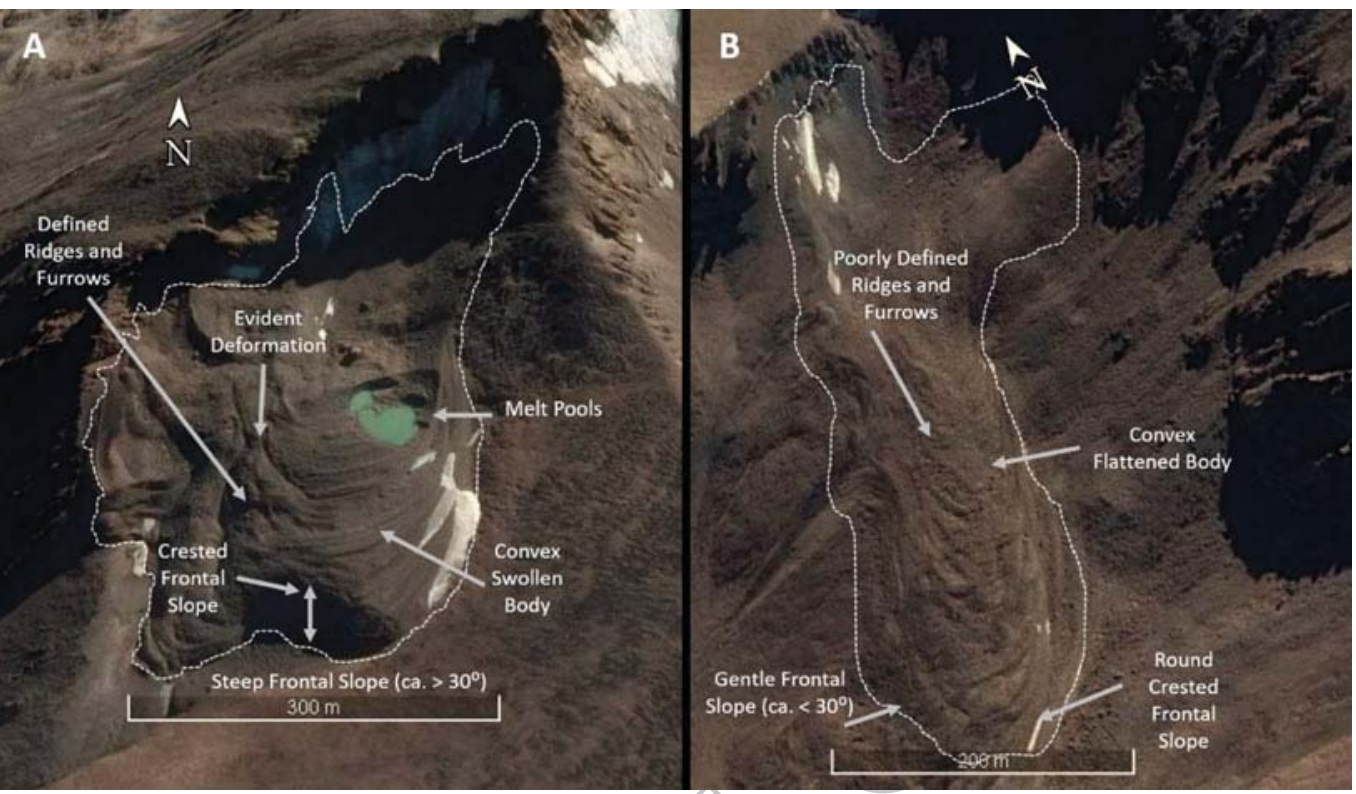

Figure 3. Annotated examples of rock glaciers: (a) Active rock glacier( $\left.46^{\circ} 58^{\prime} 30.86^{\prime \prime} \mathrm{S}, 72^{\circ} 00^{\prime} 13.94^{\prime \prime} \mathrm{W}\right)$. Image data: Google Earth Imagery (version 7.1.7.2606, Google Inc., California, USA), CNES/Airbus 2018; imagery date: 16 March 2016; and (b) Relict rock glacier $\left(47^{\circ} 01^{\prime} 08.34^{\prime \prime} \mathrm{S}, 72^{\circ} 00^{\prime} 47.17^{\prime \prime} \mathrm{W}\right)$. Image data: Google Earth Imagery (version 7.1.7.2606, Google Inc., California, USA), CNES/Airbus 2018; imagery date: 29 February 2016.

The rock glacier spatial density is $3.2 \%$ of the study region. This compares with sites in drier areas in the north in the Andes e.g. 2.2\% at Valles Calchaquíes region (Falaschi et al. 2014) and 4\% in the

AQ8 Andes between Santiago and Mendoza (Azócar and Brenning 2010). The spatial density is more than twice that reported by Ealaschi et al. (2015) (1.4\%) in the Monte San Lorenzo Massif 50km to the south.

The proportion of rock glaciers identified on each aspect was calculated and is summarized in Figures 7 and 8 . Some $80 \%$ of rock glaciers identified occurred on south, south east or south west slopes (Figure 7), although only $12 \%$ of slopes are oriented to the south west and $11 \%$ to the south east (Figure 8). The activity level of these populations illustrate different dominant aspects with $58 \%$ of relict rock glaciers developed on south easterly slopes and $41 \%$ of active rock glaciers on south westerly aspects. This suggests that in this region southerly slopes have higher propensity than other aspects for the formation and persistence of rock glaciers.

The mean PISR for the study area was $150,088 \pm 79,215 \mathrm{WHm}^{2}$ compared to $109,130 \pm$ $33,836 \mathrm{WHm}^{2}$ and $153,810 \pm 38,930 \mathrm{WHm}^{2}$ for active and relict rock glaciers means respectively. There is a significant difference between PISR median values for active rock glaciers (92017) compared to relict rock glaciers $(149715)(\mathrm{W}=1915, \mathrm{P}=0.002)$ with active rock glaciers occurring in areas of lower PISR (Figure 9).

Table 2. Morphological characteristics of Active/Inactive and Relict rock glaciers.

Identified Characteristic

\begin{tabular}{|c|c|c|c|}
\hline Features & Relict & Intact / Active & Justification \\
\hline Surface Texture & $\begin{array}{l}\text { Poorly defined ridges and } \\
\text { furrows }\end{array}$ & $\begin{array}{l}\text { Well defined ridges and furrows, indicating signs } \\
\text { of deformation and movement. }\end{array}$ & $\begin{array}{l}\text { Kääb and Weber } \\
\text { (2004) }\end{array}$ \\
\hline Body of Rock Glacier & $\begin{array}{l}\text { Flattened body suggesting } \\
\text { melting of ice. }\end{array}$ & Swollen body suggesting ice. & $\begin{array}{l}\text { Baroni et al. } \\
\text { (2004) }\end{array}$ \\
\hline Frontal Ramp & Gently sloping $\leq 30^{\circ}$ & Steep $\geq 30^{\circ}$ & $\begin{array}{l}\text { Baroni et al. } \\
\text { (2004) }\end{array}$ \\
\hline
\end{tabular}


305

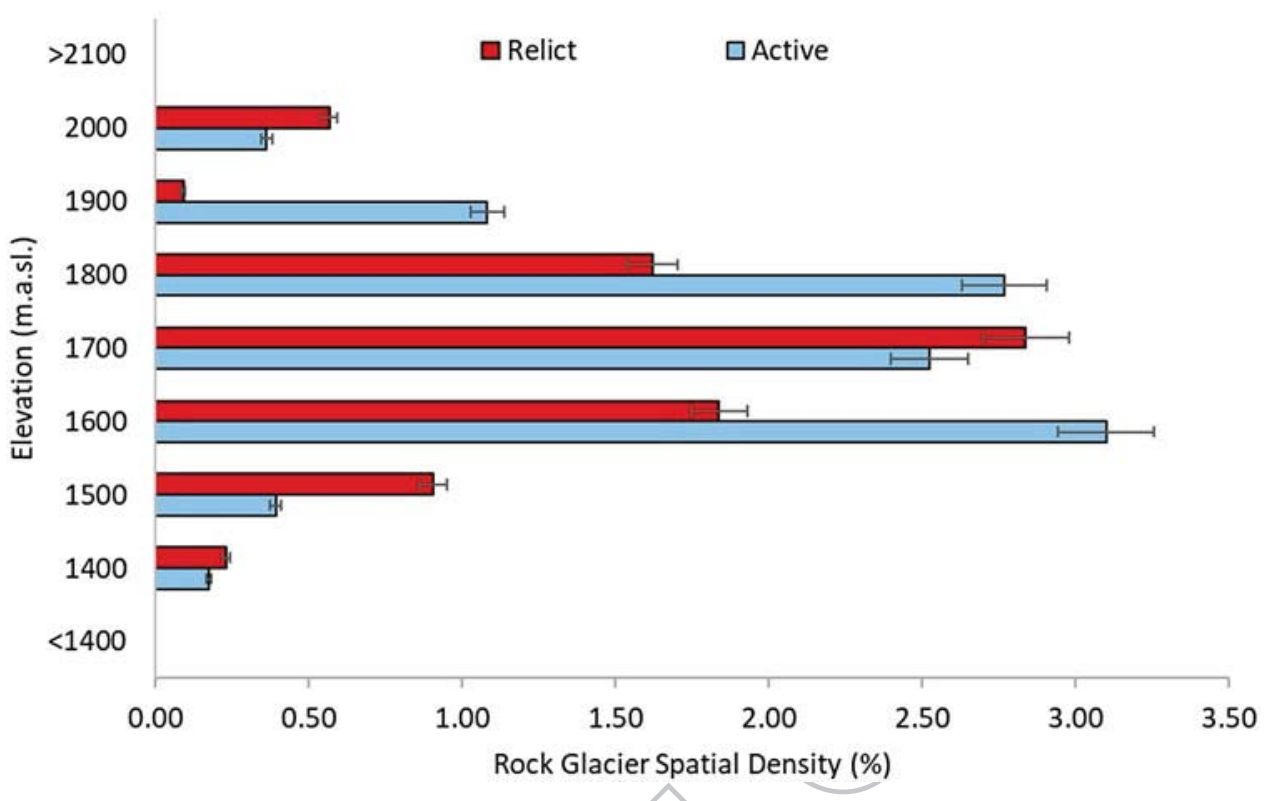

Figure 4. Distribution of rock glaciers by elevation. Variations of density through elevation bands.

\section{Discussion}

Previous work in Patagonia (Falaschi et al.2015) confirms the presence of rock glaciers in the mountains east of the current NPI in valleys draining Monte San Lorenzo and in this study we extend this work to demonstrate the conditions under which they are found in the Jeinimeni region, some $50 \mathrm{~km}$ to the north. On Cerro San Lorenzo the rock glaciers identified by Falaschi et al. (2015) were smaller in size than those in Jeinimeni (active rock glaciers average $92,000 \mathrm{~m}^{2}$ in San Lorenzo compared with $156,000 \mathrm{~m}^{2}$ in Jeinimeni) with similar trends in relict features $\left(36,000 \mathrm{~m}^{2}\right.$ compared with $164,000 \mathrm{~m}^{2}$ ). The reasons for this are currently unclear, but may include differences in local climate or geology driying variations in debris supply.

In Jeinimeni 89\% of rock glaciers occur between 1600 and 1900 m.a.s.l, the remainder above this. It has been suggested that elevation is a function of the number of available topographic and climatic niches in which rock glaciers can develop (Brenning and Trombotto 2006; Kinworthy 2016), and the MAF is commonly considered a good approximation of the limit of discontinuous permafrost (Scotti et al. 2013). However, as there was no significant difference between the MAF elevation of active and relict rock glacier in the study region it suggests additional factors control the activity level of rock glaciers in the region.

A climatic control is suggested by the preferential development of rock glaciers (80\%) on southerly aspects with low solar insolation (Krainer and Ribis 2012), despite there being a relatively even distribution between northern and southern aspects within the study area and thereby likely available topographical niches (Figures 7 and 8) and this is supported by our analysis of PISR (Figure 9(a and b)). Moreover, aspect (unlike elevation) appears to control whether the rock glaciers are relict or active. The majority of the relict rock glaciers are located on slopes with a southeast facing aspect whereas those identified as being currently active are more broadly distributed across all southward facing slopes but particularly on those with a southwest aspect. Falaschi et al. (2015) also report a strong west-south-westerly orientation of active rock glaciers to the south of Jeinimeni. Without further research it is hard to draw a concrete conclusion from this observation though it does somewhat tantalisingly suggest that the change in aspect with relict to active rock glaciers may correspond 

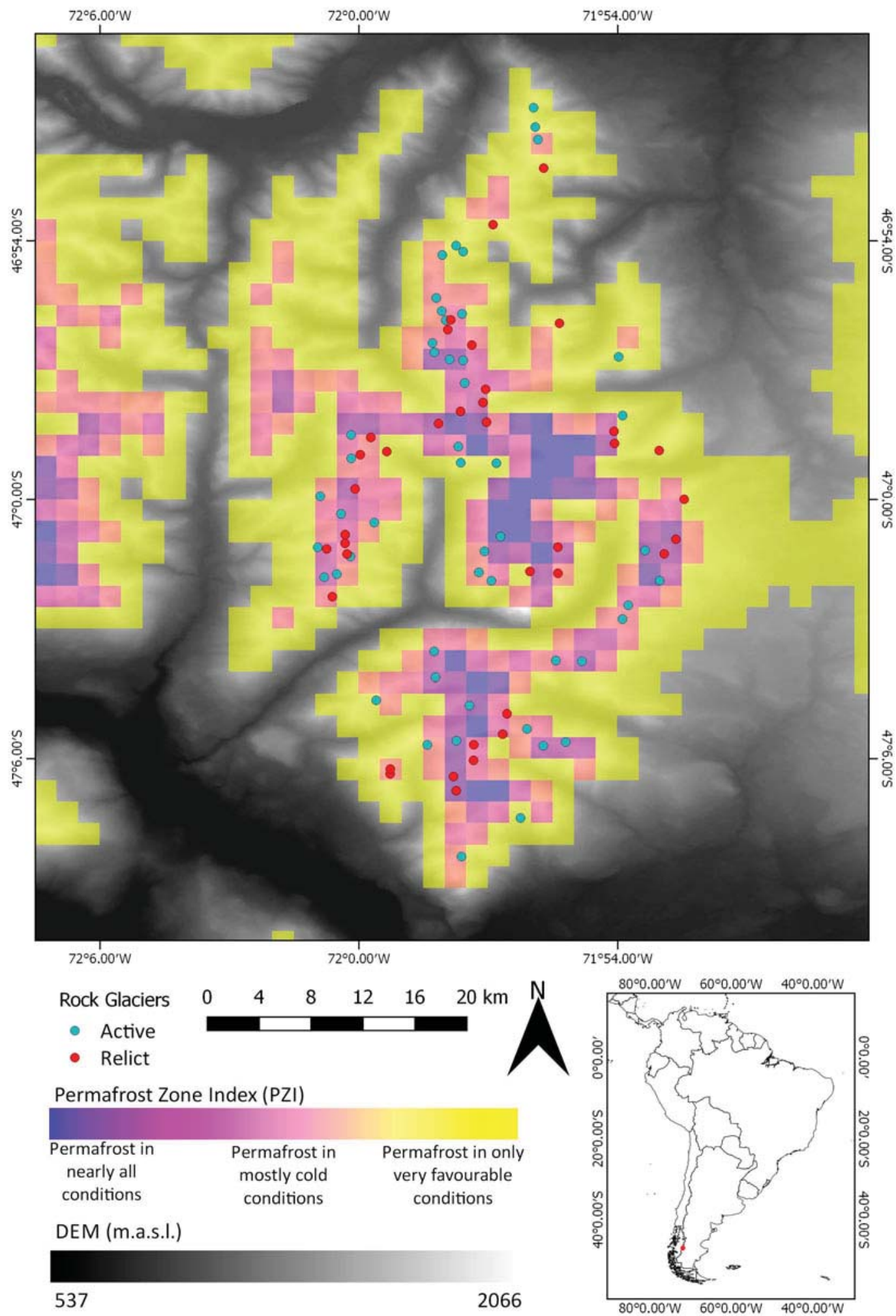

400 AQ6 Figure 5. Permafrost Zone Index (PZI) from Gruber (2012) indicating all rock glaciers occur within the likely permafrost zone. There appears to be no strong relationship between active and relict rock glaciers and strength of permafrost zone. Image data: Aster GDEM product of NASA and METI (2009). 


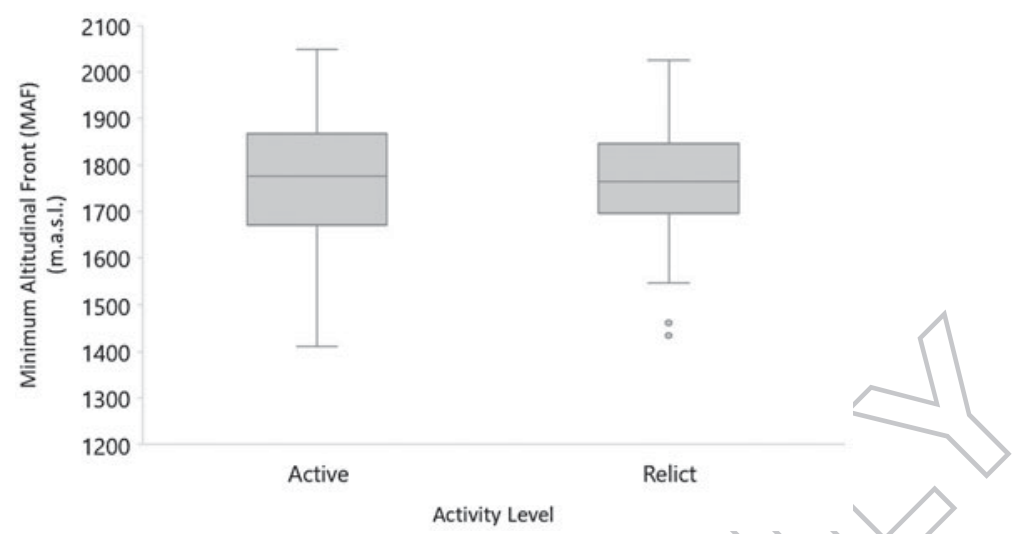

Figure 6. Box plot showing similarity in elevation of MAF between active and relict rock glaciers. 51 active rock glaciers and 38 relict rock glaciers are shown along with 2 outliers.

to a prior shift in prevailing winds, and hence snow-drift, from the west to more northerly flow in recent times.

In essence, we have shown that the active and relict rock glaciers share similar elevations and if the distinction between them is climatic then this pattern is difficult to explain. Falaschi et al. (2015) suggested that some intact rock glaciers might exist above the $0^{\circ} \mathrm{C}$ MAAT conditions illustrating permafrost persisting in positive air temperatures (Gruber and Haeberli 2007). In this case their preservation could be a consequence of the protective active layer and an indication that they are in disequilibrium with present thermal conditions (Gruber and Haeberli 2007). However, rock glaciers could also achieve thermal equilibrium due to topographical factors (Haeberli 1983; Falaschi et al. 2015). For example, circulation of cold air from glaciers or topographic shading (Brenning 2005) can influence rock glacier preservation. The evident differences observed in aspect and therefore the amount of incoming solar radiation would support the latter conclusion for this region.

However, we speculate that another possibility exists. It may be that our inventory has captured a number of features that are currently undergoing the transition from formerly debris-covered glaciers to rock glaciers. We speculate that these were formerly active glaciers, most probably during the regional Little Ice Age (or perhaps earlier), but have since undergone many years of negative mass balance and are now at various stages of transition from debris-covered glaciers to rock glaciers (Huss and Fischer 2016; Jones et al. 2018). We therefore find both active and fossil rock glaciers at broadly similar elevations as they undergo this transition at slightly different rates - other factors such as debris supply and availability determine where each landform currently is on this transition. More work is required to test this assertion.

In the absence of a large-scale dating programme the age of the rock glaciers is difficult to establish. It might be that they started to develop immediately after deglaciation of the region following the regional LGM as the expanded PIS withdrew to the west from the Chacabuco and Jeinimeni regions (Boex et al. 2013; Wolff et al. 2013). Alternatively, as suggested above, they might have developed much later during the Holocene, perhaps in response to climatic amelioration following Neoglacial times or the regional Little Ice Age at the end of the nineteenth century.

If we accept the former hypothesis then the timing of ice sheet recession following the LGM is important. Hubbard et al. (2005) reconstructed the dynamics and evolution of late Quaternary ice sheets across the NPI using a first-order coupled climate/ice sheet model described fully in Hubbard (2006), and which extends a combined empirical/modelling approach first adopted for investigating the fluctuations of the Lago Rupanco and Puyehue outlet lobes in northern Patagonia (Hubbard, 1997). Using dated end moraines to broadly constrain the model, Hubbard et al. (2005) demonstrate that the Jeinimeni region broadly deglaciated between 14.5 to $13.0 \mathrm{ka}$ BP. Complete retreat of the 


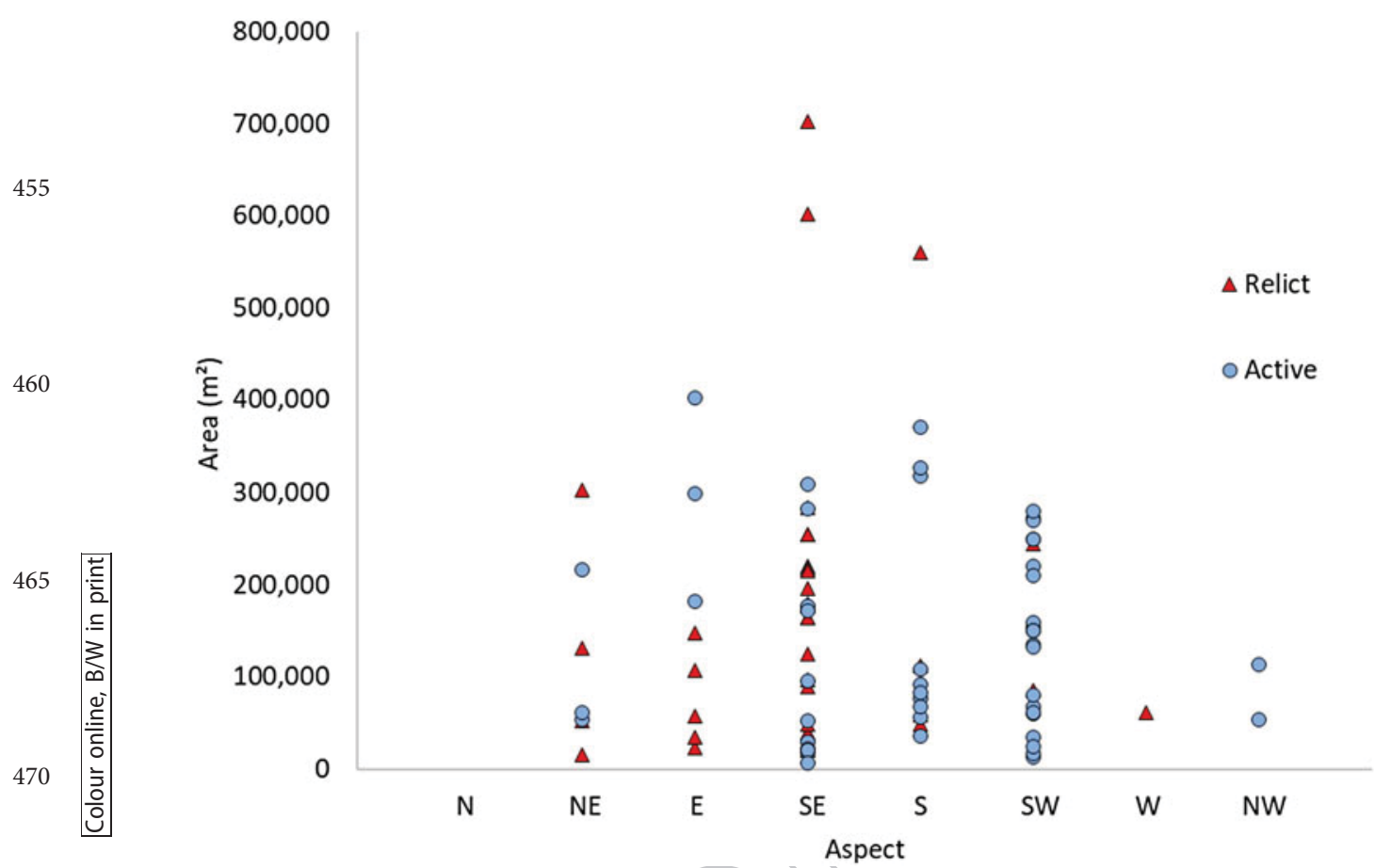

Figure 7. Rock glacier size and slope orientation. There is no evident pattern of orientation and rock glacier size. Two large outliers occur on south east aspects.

495
W
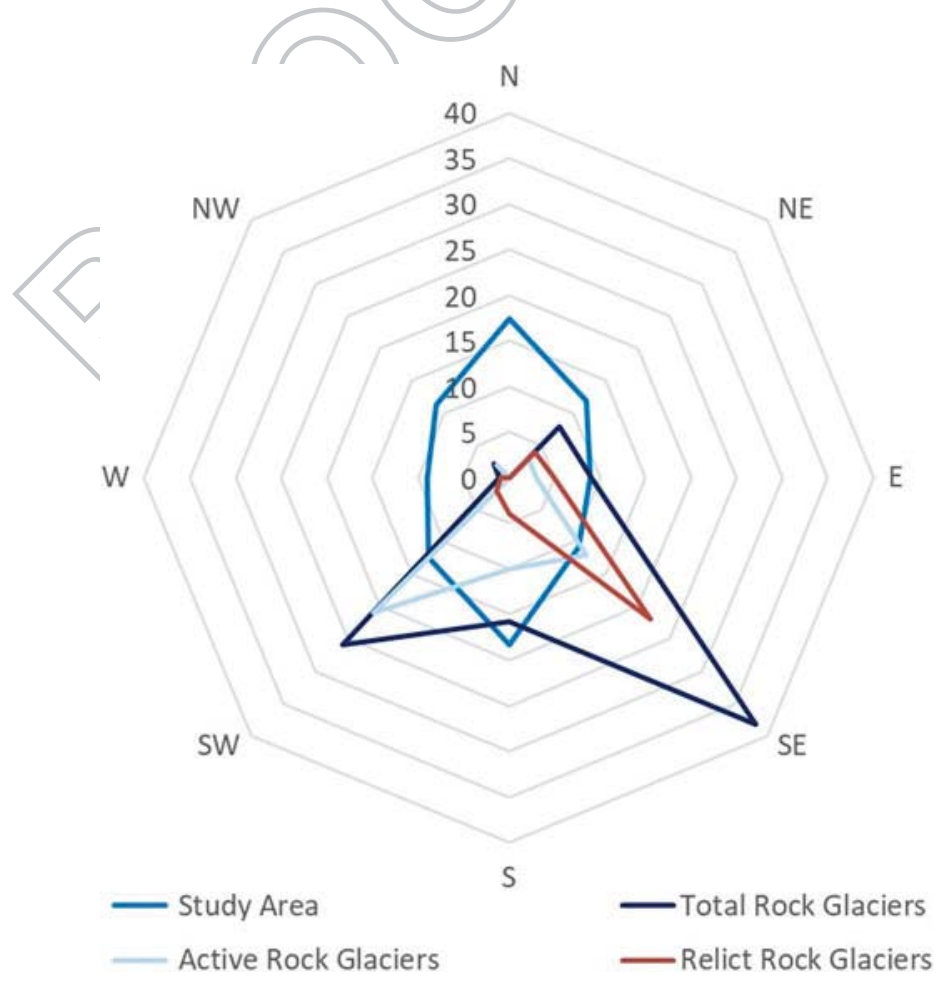

Figure 8. Spatial density of slope orientation plotted against rock glacier distribution. Active rock glaciers predominantly occur on south westerly slopes whilst relict rock glaciers occur on south easterly slopes. 


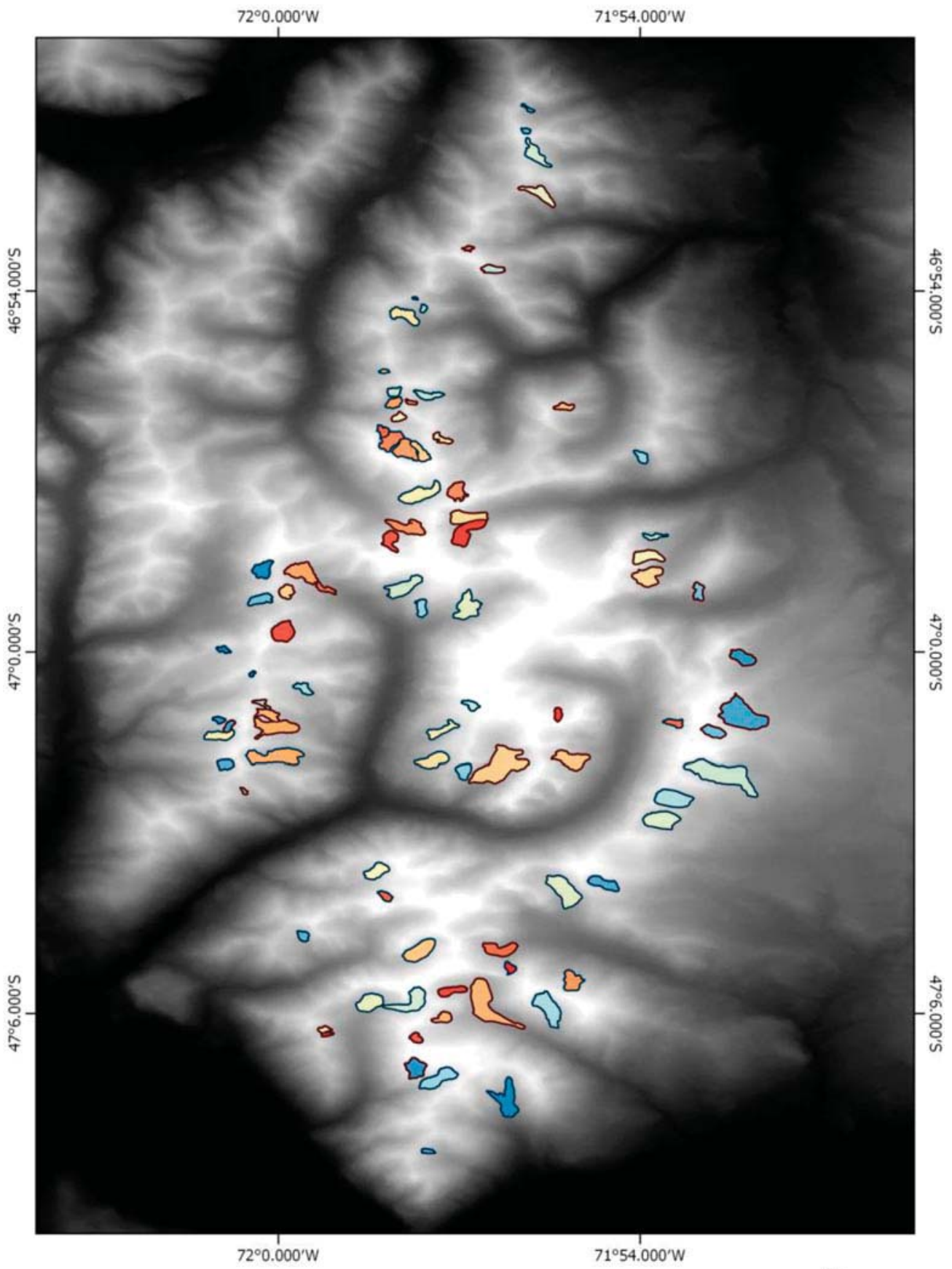

Mean Potential Incoming Solar Radiation $\left(\mathrm{WHm}^{2}\right)$
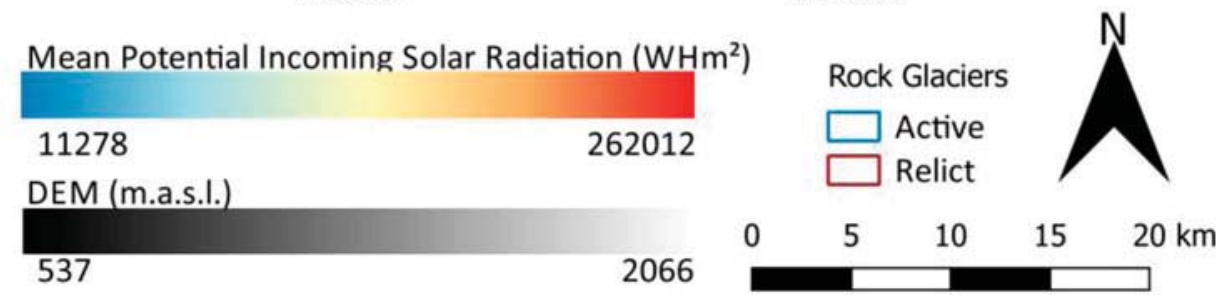

Figure 9. Potential Incoming Solar Radiation (PISR) for sites with active and relict and active rock glaciers illustrating mean values. Active rock glacier sites had significantly lower PISR median values, 92017 and 149715 respectively $(W=1915, P=0.002)$ than sites with relict features. (Image data: Aster GDEM product of NASA and METI (2009)) 


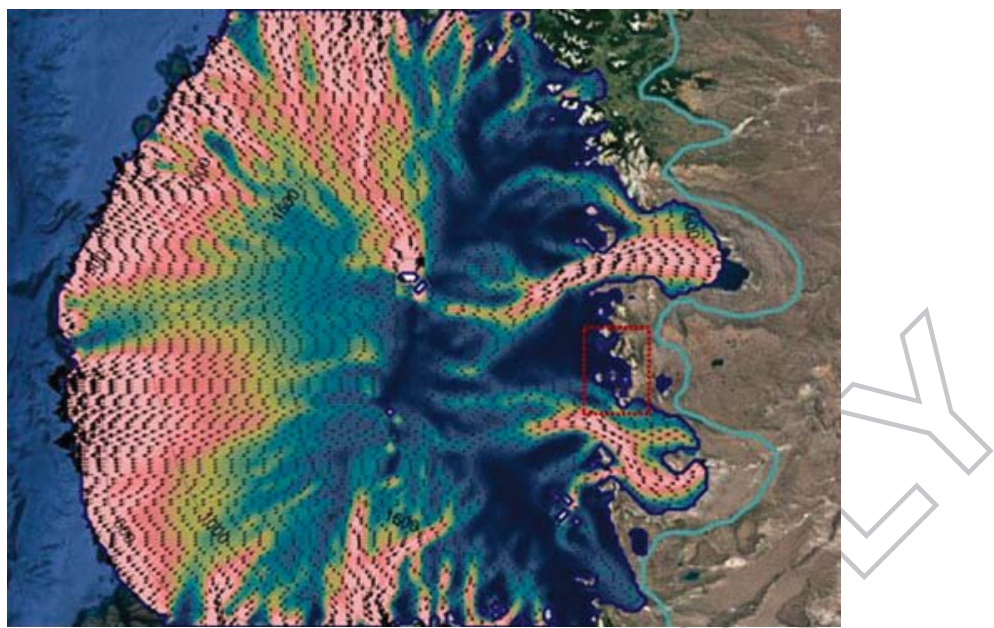

Figure 10. Model snapshot of the retreat of the Patagonian ice sheet (PIS) at c/13.5 ka BP (from Hubbard et al. 2005). The Jeinimeni study area (red box) is bounded by two major outlet glaciers, the Lago General Carerra/Buenos Aires lobe to the north and the Lago Cochrane lobe to the south, both of which had fully retreated westward of the study area by $12.5 \mathrm{ka}$ BP. Climatic and permafrost conditions conducive to local rock glacier formation would have proceeded with the onset of regional deglaciation.

Lago General Carrera/Buenos Aires outlet glacier from the area was finally accomplished by $\sim 12.5 \mathrm{ka}$ BP (Figure 10). Despite considerable recession of the PIS, cool/dry glacial conditions conducive to the formation local cirque glaciers and larger valley glaciers, persisted in the area for at least another $\sim 1.5 \mathrm{ka}$, until $\sim 11.0 \mathrm{ka}$ BP when regional climate ameliorated to conditions similar to today. During this post-glacial episode, the local equilibrium line altitude (ELA) fluctuated between $400 \mathrm{~m}$ lower than present, to around $100 \mathrm{~m}$ higher than present (for a brief 200 year period around 11.4$11.3 \mathrm{ka} \mathrm{BP}$ ) and which is in general agreement with the modelling further north (Hubbard, 1997). Given the predominantly arid climate across the region, these ELA fluctuations equate to a mean temperature range of -3.6 to $+0.9^{\circ} \mathrm{C}$ relative to present (Hubbard et al. 2005). Such conditions would have been conducive to the development of thick permafrost and formation of rock glaciers in the mountainous Jeinimeni region, likely persisted for the subsequent 11,000 years through to recent times. Finally, between 13 and $8 \mathrm{ka}$ BP large lakes existed to the east of the current NPI covering an area of $\sim 7400 \mathrm{~km}^{2}$, around four times the current area of Lago General Carrera/Buenos Aires (Glasser et al. 2016). In the Chacabuco valley delta features as high as 700 m.a.s.l. indicate the existence of former lakes at this time and as these drained during the early Holocene increasing aridity would likely have favoured the development of rock glaciers in the mountains to the north, and at the recently deglaciated sites. Given this we could also speculate that the rock glaciers developed following deglaciation and persisted on southerly slopes due to lower solar insolation. Clearly, more research is required to test these hypotheses.

\section{Conclusions}

We have produced a preliminary rock glacier inventory for the mountains in the Jeinimeni region of central Patagonia and have demonstrated that active and relict rock glaciers are widely developed in the mountains between 1412 and 2049 m.a.s.l to the east of the present-day North Patagonian Icefield. In total 89 rock glaciers were identified and mapped and they cover $14.18 \mathrm{~km}^{2}$ of the study area. The inventory comprises 51 active rock glaciers (covering $7.94 \mathrm{~km}^{2}$ ) and 38 relict rock glaciers (covering $6.24 \mathrm{~km}^{2}$ ). We show that they are preferentially developed on slopes with a south-facing orientation and active rock glaciers are preserved in areas of lower PISR indicating strong solar radiation control. 


\section{Acknowledgements}

A.H. acknowledges support from the Centre for Arctic Gas Hydrate, Environment and Climate, funded by the Research Council of Norway through its Centres of Excellence (grant 223259).

605

\section{Disclosure statement}

No potential conflict of interest was reported by the authors.

\section{Funding}

A.H. acknowledges support from the Centre for Arctic Gas Hydrate, Environment and Climate, funded by the Research Council of Norway through its Centres of Excellence (Grant no 223259).

\section{Notes on Contributors}

Heather Selley is undertaking a $\mathrm{PhD}$ research project at Leeds University using high resolution altimetry data to investigate the mass balance Greenland and Antarctica.

Stephan Harrison is at Exeter University and works on the impacts of climate change in mountain systems. He has worked for many years in Patagonia, and also in the tropical Andes and the Himalaya.

Neil Glasser is at Aberystwyth University and studies the evolution and behaviour of glaciers and ice sheets, mainly in Patagonia, the Himalayas and Antarctica.

Olaf Wündrich is a surveyor and mountain guide working in the mountains of Patagonia.

Daniel Colson is a remote sensing and GIS specialist.

Alun Hubbard is a glaciologist at Aberystwyth University and the Arctic University of Norway in Tromsø. His research is focuses on climate, ocean and ice sheet interactions in Polar and Alpine regions.

\section{References}

Angillieri MYE. 2009. A preliminary inventory of rock glaciers at $30 \mathrm{~S}$ latitude, Cordillera frontal of San Juan,

630 AQ9 Argentina. Quat Int. 195(1):151-157.

Baroni C, Carton A, Seppi R. 2004. Distribution and behaviour of rock glaciers in the Adamello-Presanella Massif (Italian Alps). Perm Periglac Process. 15(3):243-259.

Barsch D. 1978. Active rock glaciers as indicators for discontinuous alpine permafrost. An example from the Swiss Alps. In: Proceedings of the third international conference on permafrost. (1):349-352.

Barsch D. 1992. Permafrost creep and rock glaciers. Perm Periglac Process. 3(3):175-188.

Barsch D. 1996. Rock glaciers - indicator for the present and former geoecology in high mountain environments. Berlin: Springer.

AQ10 Benn D, Evans DJ. 2014. Glaciers and glaciation. Routledge.

Berthling I. 2011. Beyond confusion: rock glaciers as cryo-conditioned landforms. Geomorphology. 131(3):98-106.

Berthling I, Etzelmüller B. 2007. Holocene rockwall retreat and the estimation of rock glacier age, Prins Karls Forland, Svalbard. Geografiska Annaler: Ser A, Phys Geogr. 89(1):83-93.

640 Boex J, Fogwill C, Harrison S, Glasser NF, Hein A, Schnabel C, Xu S. 2013. Rapid thinning of the late Pleistocene

AQ11 Patagonian Ice sheet followed migration of the Southern Westerlies. Sci Rep. 3.

Brenning A. 2005. Geomorphological, hydrological and climatic significance of rock glaciers in the Andes of central Chile (33-35 S). Perm Periglac Process. 16(3):231-240.

Brenning A, Long S, Fieguth P. 2012. Detecting rock glacier flow structures using Gabor filters and IKONOS imagery. Remote Sens Environ. 125:227-237.

645 Brenning A, Trombotto D. 2006. Logistic regression modelling of rock glacier and glacier distribution: topographic and climatic controls in the semi-arid Andes. Geomorphoogy. 81(1):141-154.

Burger KC, Degenhardt JJ, Giardino JR. 1999. Engineering geomorphology of rock glaciers. Geomorphology. 31(1):93132.

Burrough PA, McDonnell R, McDonnell RA, Lloyd CD. 2015. Principles of geographical information systems. Oxford AQ12 University Press.

650

Chueca J. 1992. A statistical analysis of the spatial distribution of rock glaciers, Spanish Central Pyrenees. Perm Periglac Process. 3(3):261-265. 
Degenhardt JJ. 2009. Development of tongue-shaped and multilobate rock glaciers in alpine environments-interpretations from ground penetrating radar surveys. Geomorphology. 109(3):94-107.

Degenhardt JJ, Giardino JR. 2003. Subsurface investigation of a rock glacier using ground-penetrating radar: implications for locating stored water on Mars. J Geophys Res Planets. 108(E4):383.

Dramis F, Giraudi C, Guglielmin M. 2003. Rock glacier distribution and paleoclimate in Italy. Permafr. 1:199-204.

Falaschi D, Tadono T, Masiokas M. 2015. Rock glaciers in the Patagonian Andes: an inventory for the Monte San Lorenzo (Cerro Cochrane) Massif, $47^{\circ}$ S. Geografiska Annaler: Ser A, Phys Geogr. 97(4): 769-777.

AQ13 French HM, Williams P. 2013. The periglacial environment. John Wiley \& Sons.

Giardino JR, Vitek JD. 1988. The significance of rock glaciers in the glacial-periglacial landscape continuum. J Quat Sci. 3(1):97-103.

Glasser NF, Jansson KN, Duller GA, Singarayer J, Holloway M, Harrison S. 2016. Glacial lake drainage in Patagonia (13-8 kyr) and response of the adjacent Pacific Ocean. Sci Rep. 6:289.

Gruber S, Fleiner R, Guegan E, Panday P, Schmid MO, Stumm D, Wester P, Zhang Y, Zhao L. 2017. Inferring permafrost and permafrost thaw in the mountains of The Hindu Kush Himalaya region. Cryosphere. 11(1):81-99.

Gruber S, Haeberli W. 2007. Permafrost in steep bedrock slopes and its temperature-related destabilization following climate change. J Geophys Res: Earth Surf. 112(F2):301.

Haeberli W. 1983. Permafrost-glacier relationships in the Swiss Alps-today and in the past. In: Proceedings of the fourth international conference on permafrost 1983. National Academy Press; p. 415-420.

Haeberli W, Hallet B, Arenson L, Elconin R, Humlum O, Kääb A, Kaufmann V, Ladanyi B, Matsuoka N, Springman S, Mühll DV. 2006. Permafrost creep and rock glacier dynamics. Perm and Periglac Process. 17(3):189-214.

Haeberli W, Kääb A, Wagner S, Mühll DV, Geissler P, Haas JN, Glatzel-Mattheier H, Wagenbach D. 1999. Pollen analysis and 14C age of moss remains in a permafrost core recovered from the active rock glacier MurtèlCorvatsch, Swiss Alps: geomorphological and glaciological implications. J Glaciol. 45(149):1-8.

670 Harrison S, Glasser NF. 2011. The Pleistocene glaciations of Chile. Dev Quat Sci. 15:739-756.

Harrison S, Whalley B, Anderson E. 2008. Relict rock glaciers and protalus lobes in the British isles: implications for late Pleistocene mountain geomorphology and palaeoclimate. J Quat Sci. 23(3):287-304.

Hubbard A. 1997. Modelling climate, topography and palaeoglacier fluctuations in the Chilean Andes. Earth Surf Processes Landforms. 22(1):79-92.

Hubbard A. 2006. The validation and sensitivity of a model of the Icelandic ice sheet. Quat Sci Rev. 25(17-18):22972313.

Hubbard A, Hein AS, Kaplan MR, Hulton NR, Glasser N. 2005. A modelling reconstruction of the last glacial maximum ice sheet and its deglaciation in the vicinity of the Northern Patagonian Icefield, South America. Geografiska Annaler: Ser A, Phys Geogr. 87(2):375-391.

Humlum O. 1996. Origin of rock glaciers: observations from Mellemfjord, Disko Island, central West Greenland. Permf Periglac Process. 7(4):361-380.

680 Humlum O. 2000. The geomorphic significance of rock glaciers: estimates of rock glacier debris volumes and headwall recession rates in West Greenland. Geomorphology. 35(1):41-67.

Huss M, Fischer M. 2016. Sensitivity of very small glaciers in the Swiss Alps to future climate change. Front Earth Sci. $4: 34$.

AQ14 Jansen F, Hergarten S. 2006. Rock glacier dynamics: stick-slip motion coupled to hydrology. Geophys Res Lett. 33(10)

Johnson PG. 1974. Mass movement of ablation complexes and their relationship to rock glaciers. Geografiska Annaler: Ser A, Phys Geogr. 56:93-101.

Jones DB, Harrison S, Anderson K, Selley HL, Wood JL, Betts RA. 2018. The distribution and hydrological significance of rock glaciers in the Nepalese Himalaya. Glob Planet Chang. 160:123-142.

Kellerer-Pirklbauer A, Lieb GK, Kleinferchner H. 2012. A new rock glacier inventory of the Eastern European Alps. Austrian J Earth Sci. 105(2):78-93.

Kinworthy B. 2016. New Mexico rock glacier inventory: analysis of geomorphology and paleogeography [Doctoral dissertation].

Krainer K, Ribis M. 2012. A rock glacier inventory of the Tyrolean Alps (Austria). Austrian J Earth Sci. 105(2):32-47.

Liu L, Millar CI, Westfall RD, Zebker HA. 2013. Surface motion of active rock glaciers in the Sierra Nevada, California,

AQ15 USA: inventory and a case study using InSAR. Cryosphere. 7(4):1109.

Marcer M, Bodin X, Brenning A, Schoeneich P, Charvet R, Gottardi F. 2017. Permafrost favorability index: spatial modeling in the French Alps using a rock glacier inventory. Front Earth Sci. 5:105.

Martin EH, Whalley WB. 1987. Rock glaciers: part 1: rock glacier morphology: classification and distribution. Prog Phys Geogr. 11(2):260-282.

METI and NASA. 2009. (ASTER GDEM V2). NASA EOSDIS Land Processes DAAC, USGS Earth Resources Observation and Science (EROS) Center, Sioux Falls, South Dakota (https://lpdaac.usgs.gov), Accessed 27

AQ16 January $2016<$ http://dx.doi.org/10.5067/ASTER/ASTGTM.002>

Millar CI, Westfall RD. 2008. Rock glaciers and related periglacial landforms in the Sierra Nevada, CA, USA; inventory, distribution and climatic relationships. Quat Int. 188(1):90-104. 
Monnier S, Kinnard C. 2015. Internal structure and composition of a rock glacier in the dry Andes, inferred from ground-penetrating Radar data and its Artefacts. Perm Periglac Process. 26(4):335-346.

Olyphant GA. 1983. Analysis of the factors controlling cliff burial by talus within Blanca Massif, Southern Colorado,

AQ17 USA. Arct Alp Res. 65-75.

Parson CG. 1987. Rock glaciers and site characteristics on the Blanca Massif, Colorado, USA. London: Rock Glaciers. Allen and Unwin; p. 127-144.

Paul F, Kääb A, Haeberli W. 2003. Mapping of rock glaciers with optical satellite imagery. 8th International Conference on Permafrost Extended Abstracts on Current Research and Newly Available Information. <http://wp.cedha.net/ wp-content/uploads/2011/10/Paul-et-al-2003-rgl-mapping-satellite-imagery.pdf>.

Potter N. 1972. Ice-cored rock glacier, Galena Creek, northern Absaroka Mountains, Wyoming. Geol Soc Am Bull. 83 (10):3025-3058.

710 Rangecroft S, Harrison S, Anderson K. 2015. Rock glaciers as water stores in the Bolivian Andes: an assessment of their hydrological importance. Arct Antarct Alp Res. 47(1):89-98.

Rangecroft S, Harrison S, Anderson K, Magrath J, Castel AP, Pacheco P. 2013. Climate change and water resources in arid mountains: an example from the Bolivian Andes. Ambio. 42(7):852-863.

Rangecroft S, Harrison S, Anderson K, Magrath J, Castel AP, Pacheco P. 2014. A first rock glacier inventory for the Bolivian Andes. Perm Periglac Process. 25(4):333-343.

715 Roer I, Nyenhuis M. 2007. Rockglacier activity studies on a regional scale: comparison of geomorphological mapping and photogrammetric monitoring. Earth Surf Process and Landf: The J Br Geomorphol Res Group. 32(12):17471758.

Sattler K, Anderson B, Mackintosh A, Norton K, de Róiste M. 2016. Estimating permafrost distribution in the maritime Southern Alps, New Zealand, based on climatic conditions at rock glacier sites. Front Earth Sci. 4:4.

Schmid MO, Baral P, Gruber S, Shahi S, Shrestha T, Stumm D, Wester P. 2015. Assessment of permafrost distribution maps in The Hindu Kush Himalayan region using rock glaciers mapped in google earth. Cryosphere. 9(6):20892099.

Schrott L. 1996. Some geomorphological-hydrological aspects of rock glaciers in the Andes (San Juan, Argentina). Zeit

AQ18 fur Geomorphologie Suppl. Band. 161-173.

Scotti R, Brardinoni F, Alberti S, Frattini P, Crosta GB. 2013. A regional inventory of rock glaciers and protalus ramparts in the central Italian Alps. Geomorphology. 186:136-149.

725 Seligman ZM. 2009. Rock glacier distribution, activity and movement, northern Absaroka and Beartooth ranges. MT,

AQ19 USA

Shroder JF, Bishop MP, Copland L, Sloan VF. 2000. Debris-covered glaciers and rock glaciers in the Nanga Parbat Himalaya, Pakistan. Geografiska Annaler: Ser A, Phys Geogr. 82(1):17-31.

Stenni B, Genoni L, Flora O, Guglielmin M. 2007. An oxygen isotope record from the foscagno rock-glacier ice core, Upper Valtellina, Italian Central Alps. Holocene. 17(7):1033-1039.

730AQ20 Summerfield MA. 2014. Global geomorphology. Routledge.

Trombotto D, Buk E, Hernández J. 1999. Rock glaciers in the southern central Andes (approx. 33-34 S), Cordillera Frontal, Mendoza, Argentina. Bamberger Geographische Schriften. 19:145-173.

USGS. 2015. The shuttle radar topography mission (SRTM) collection user guide. Pasadena: NASA.

Villarroel C, Carrasco JF, Casassa G, Falvey M. 2013. Modeling near-surface air temperature and precipitation using WRF with 5-km resolution in the Northern Patagonia Icefield: a pilot simulation. Intl J Geosci. 4(8):1193-1199.

Wahrhaftig C, Cox A. 1959. Rock glaciers in the Alaska Range. Geol Soc Am Bull. 70(4):383-436.

Whalley WB, Martin HE. 1992. Rock glaciers: II models and mechanisms. Prog Phys Geogr. 16(2):127-186.

White PG. 1979. Rock glacier morphometry, San Juan Mountains, Colorado: summary. Geol Soc Am Bull. 90(6):515518.

Wolff IW, Glasser NF, Hubbard A. 2013. The reconstruction and climatic implication of an independent palaeo ice cap within the Andean rain shadow east of the former Patagonian ice sheet, Santa Cruz Province, Argentina. Geomorphology. 185:1-15. 